\title{
Logistics digital transformation model based on a platform solution
}

\author{
Aleksandr Kozlov $^{1,}$, Anna Smirnova ${ }^{1}$, Irina Zaychenko ${ }^{1}$, Yevhenii Shytova ${ }^{1}$, and Joanna \\ Kalkowska ${ }^{2}$ \\ ${ }^{1}$ Peter the Great St. Petersburg polytechnic University, Institute of Industrial Economics, Management \\ and Trade, 195251 St. Petersburg, Russia \\ ${ }^{2}$ Poznan University of Technology, Poznan, Poland
}

\begin{abstract}
This paper is devoted to researching the major aspects of the digital transformation of the logistical field. Provided are the suggestions for constructing logistical process stakeholder interaction models. One of the major trends in digital logistics is platform solutions that will come to replace specialized digital solutions. Based on this trend, authors provide the 3-level model of stakeholder interaction on the logistical platform which could form the foundation of a future platform solution architecture. The creation of the logistical platform is the next step in the digital transformation of logistics which aims to create a unified logistical ecosystem.
\end{abstract}

\section{Introduction}

Logistics was among the first industries pioneering in implementation of the digital transformation of businesses. The application of various digital technologies has allowed calculating the economic benefits related to the integration of IT solutions into logistical processes, thus demonstrating their efficacy. The cutting-edge technologies such as machine learning, Big Data, digital alter egos and others have become the subjects of wide implementation in logistical chain optimization. Previously the main issue was the implementation of the end-to-end technologies in principle. The contemporary discussion is now centered on the creation of the unified digital solutions ecosystem for the logistical field.

This paper aims to create the model for stakeholder interactions under the unified framework of a digital logistical platform.

The digital logistics at this stage of digital economy development is one of the crucial fields for the research related to studying the economic impacts of implementing digital technologies in businesses. The different aspects of this subject were studied by various Russian and foreign researchers. In particular, Koroleva A.A. [1] described the economic impacts of the digital logistics, Terenina I.V. and Skovorodneva E.V. [2] provided the strategy for the digital transformation of service logistics; Bordunov I.V. [3] studied the problem of digitalization of logistical chains, et cetera.

\footnotetext{
* Corresponding author: avk55-spb@yandex.ru
} 
The applicability of the subject of the digital transformation of logistics is immense as demonstrated by the frequency of usage of the keyword "digital logistics" from the year 2014 onwards (fig 1)

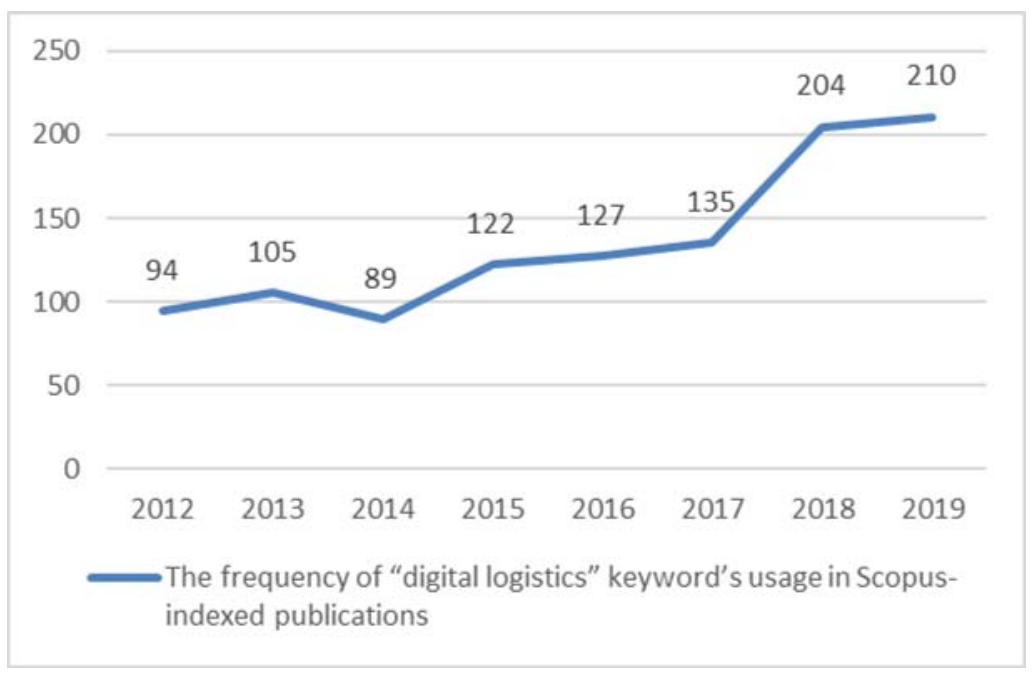

Fig. 1. The frequency of "digital logistics" keyword's usage in Scopus-indexed publications.

The crucial aspect of studying the digital transformation of logistics is the multidisciplinary approach. This problem is studied by specialists from such diverse fields as medical, computer sciences, engineering, math, and social studies. This proves that the effects of the digital transformation of logistics impact many areas of human life, which, once again, underlines the applicability of this paper.

\section{Materials and Methods}

Before the strategy of the digital transformation of logistics can be studied in detail, we should bring clarity to the terms used in this paper. In particular, in this paper, the term "digital transformation" designates the transition of the traditional system of control into the one based on innovation and information and communication technologies dedicated to optimizing and automating business-related processes and expenses. This paper is based on Koroleva's [1] definition of "digital logistics" - the "digitization of cargo transportation involving intellectual control and freight tracking systems during the entirety of cargo transportation process, unmanned technologies and the full automation of document flow in service of logistical processes within country borders as well as internationally with the usage of fast customs processing".

The digital transformation of logistics is a vital part of the digital economy. In 2018, Russia formulated the program titled "The digital economy of the Russian Federation" [4]. This program was adopted on the 7 May 2018 under Presidential Decree number 204 "Regarding the national goals and strategic targets for the development of the Russian Federation during the period up to the year 2024" and enacted on 24 December 2018 during the session of the Presidential Council of the strategic development and national projects. The national program includes 7 federal projects dedicated to the development of digital technologies, IT infrastructure, personnel, informational security, digital bureaucracy, and the legal regulations related to the digital environment and artificial intelligence.

The national program delineates 9 "end-to-end" digital technologies:

1. Big Data 
2. Quantum technologies

3. Robotics and sensors

4. Neural technologies and AI

5. "New manufacturing technologies"

6. Industrial Internet

7. Blockchain systems

8. Wireless communication technologies

9. AR and VR technologies.

The majority of these "end-to-end" technologies found their application in logistics. The levels of digital technology usage were described by experts from the First National Consulting Group and are provided in fig 2 [5].

\section{Digital Utilization Levels}

\begin{tabular}{|c|c|c|c|c|}
\hline $\begin{array}{c}\text { Transport } \\
\text { logistics }\end{array}$ & $\begin{array}{c}\text { Centralized } \\
\text { transport } \\
\text { management }\end{array}$ & $\begin{array}{c}\text { Predictive } \\
\text { capacity } \\
\text { utilization policy }\end{array}$ & $\begin{array}{c}\text { Real-time } \\
\text { tracking }\end{array}$ & $\begin{array}{c}\text { Automatic and } \\
\text { unmanned } \\
\text { vehicles }\end{array}$ \\
\hline $\begin{array}{c}\text { Warehouse } \\
\text { logistics }\end{array}$ & $\begin{array}{c}\text { Automatic } \\
\text { warehouse } \\
\text { management } \\
\text { system }\end{array}$ & $\begin{array}{c}\text { Warehouse } \\
\text { network } \\
\text { management } \\
\text { system }\end{array}$ & $\begin{array}{c}\text { Integration of the } \\
\text { warehouse } \\
\text { network into the } \\
\text { supply chain }\end{array}$ & $\begin{array}{c}\text { Lack of need for } \\
\text { a warehouse }\end{array}$ \\
\hline $\begin{array}{c}\text { Intelligent } \\
\text { Network } \\
\text { Design }\end{array}$ & $\begin{array}{c}\text { Local operating } \\
\text { structures }\end{array}$ & $\begin{array}{c}\text { Global operating } \\
\text { structure }\end{array}$ & $\begin{array}{c}\text { Use of the global } \\
\text { ERP in terms of } \\
\text { functions }\end{array}$ & Global use ERP \\
\hline $\begin{array}{c}\text { Purchasing } \\
\text { logistics }\end{array}$ & $\begin{array}{c}\text { The "push" } \\
\text { delivery } \\
\text { management } \\
\text { process }\end{array}$ & $\begin{array}{c}\text { Pulling } \\
\text { management } \\
\text { process }\end{array}$ & $\begin{array}{c}\text { Automatic IT } \\
\text { Inventory } \\
\text { Management } \\
\text { System }\end{array}$ & $\begin{array}{c}\text { Predictive } \\
\text { purchasing policy }\end{array}$ \\
\hline $\begin{array}{c}\text { Internal } \\
\text { logistics }\end{array}$ & Hand carts & $\begin{array}{c}\text { Partial carts } \\
\text { automation }\end{array}$ & $\begin{array}{c}\text { Unmanned } \\
\text { automatic carts }\end{array}$ & $\begin{array}{c}\text { Production } \\
\text { Facility } \\
\text { Management Cart }\end{array}$ \\
\hline $\begin{array}{c}\text { External } \\
\text { logistics }\end{array}$ & $\begin{array}{c}\text { Delivery policy } \\
\text { based on orders }\end{array}$ & $\begin{array}{c}\text { Active delivery } \\
\text { management } \\
\text { process }\end{array}$ & $\begin{array}{c}\text { Automatic } \\
\text { delivery } \\
\text { management }\end{array}$ & $\begin{array}{c}\text { Predictive } \\
\text { delivery } \\
\text { management }\end{array}$ \\
\hline
\end{tabular}

Fig. 2. Levels of digital technology usage.

According to the data [6], logistics is one of the top five economic sectors in the Russian Federation according to the level of digitalization. However, only $28 \%$ of companies rank their level of digitalization as "advanced". Despite logistics being one of the leading fields in regards to the digital transformation in Russia, according to the global logistical efficiency index, Russia occupies only the 75th position (Table 1). This indicates that the formation of digital logistics requires a very complex approach to its growth. 
Table 1. Global logistical efficiency index (Source: [7]).

\begin{tabular}{|c|c|c|c|c|c|c|c|c|c|c|c|c|c|c|c|}
\hline \multirow{2}{*}{$\stackrel{\vec{E}}{E}$} & \multirow{2}{*}{ 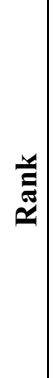 } & \multirow{2}{*}{ 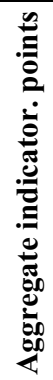 } & \multirow{2}{*}{ 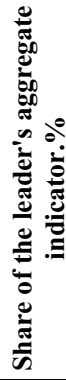 } & \multicolumn{2}{|c|}{ 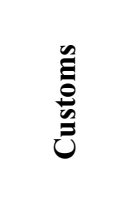 } & \multicolumn{2}{|c|}{ 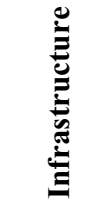 } & \multicolumn{2}{|c|}{ 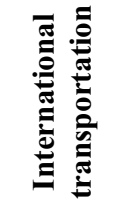 } & \multicolumn{2}{|c|}{ 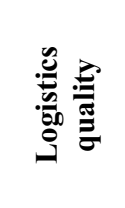 } & \multicolumn{2}{|c|}{ 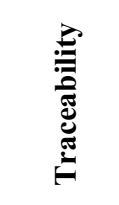 } & \multicolumn{2}{|c|}{ 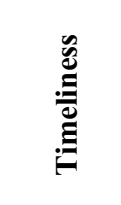 } \\
\hline & & & & 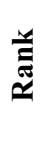 & : & 气 & : & 气ै & 总 & 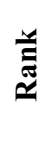 & 苞 & 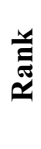 & 苛 & שֶ & : \\
\hline Germany & - & 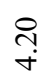 & $\stackrel{\circ}{8}$ & - & $\underset{+}{\stackrel{\partial}{+}}$ & - & $\stackrel{\tilde{m}}{+}$ & 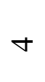 & $\begin{array}{l}\infty \\
\infty \\
r\end{array}$ & - & $\vec{m}$ & $N$ & $\underset{+}{\stackrel{+}{+}}$ & $m$ & ले \\
\hline Sweden & $\sim$ & $\stackrel{n}{o}$ & $\stackrel{+}{a}$ & $N$ & $\stackrel{n}{\circ}$ & $m$ & $\stackrel{\text { i }}{+}$ & $N$ & $\underset{\alpha}{\sigma}$ & $ㅇ$ & $\begin{array}{l}\infty \\
\text { ஸे }\end{array}$ & $\Xi$ & $\begin{array}{l}\infty \\
\infty \\
\dot{m}\end{array}$ & $r$ & $\stackrel{\infty}{\sim}$ \\
\hline Belgium & $m$ & $\underset{+}{\stackrel{+}{+}}$ & शे & \pm & $\begin{array}{l}8 \\
\dot{r}\end{array}$ & $\Xi$ & $\stackrel{\infty}{\stackrel{\infty}{~}}$ & - & gे & $N$ & $\stackrel{m}{\dot{r}}$ & $a$ & $\stackrel{\leftrightarrow}{2} \stackrel{+}{+}$ & - & $\vec{\nabla}$ \\
\hline Austria & $\nabla$ & $\begin{array}{l}\tilde{\sigma} \\
\dot{+}\end{array}$ & $\stackrel{n}{a}$ & $\simeq$ & $\vec{r}$ & $n$ & $\stackrel{\infty}{\stackrel{\sim}{\sigma}}$ & $m$ & $\begin{array}{l}\infty \\
\infty \\
\dot{m}\end{array}$ & 6 & $\stackrel{\infty}{\stackrel{\infty}{+}}$ & r & $\underset{+}{\stackrel{\partial}{0}}$ & $\simeq$ & $\stackrel{\overbrace{}}{\sim}$ \\
\hline Japan & $n$ & $\stackrel{\wp}{\sigma}$ & $\stackrel{n}{a}$ & $m$ & के & $N$ & $\stackrel{\sim}{\sim}$ & \pm & nे & $\nabla$ & $\underset{\dot{\sigma}}{\stackrel{\theta}{+}}$ & 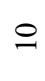 & $\begin{array}{l}n \\
\dot{\sigma}\end{array}$ & 으 & $\stackrel{\sim}{\sim}$ \\
\hline Netherlands & 0 & $\begin{array}{l}\widetilde{\sigma} \\
\stackrel{+}{+}\end{array}$ & $\stackrel{n}{a}$ & in & ๙ू & $\nabla$ & $\vec{\sim}$ & $=$ & $\begin{array}{l}\infty \\
\dot{\infty} \\
\dot{m}\end{array}$ & in & $\stackrel{8}{\circ}$ & $=$ & $\stackrel{\sigma}{\sigma}$ & $=$ & 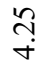 \\
\hline Singapore & $r$ & $\stackrel{8}{\&}$ & $\begin{array}{l}\stackrel{\sigma}{a} \\
\dot{\sigma}\end{array}$ & 0 & $\begin{array}{l}\infty \\
\dot{m}\end{array}$ & 0 & $\stackrel{8}{\circ}$ & $n$ & $\stackrel{\infty}{n}$ & $m$ & $\stackrel{\circ}{\stackrel{+}{r}}$ & $\infty$ & $\stackrel{\infty}{\infty}$ & 6 & $\stackrel{\sim}{\sim}$ \\
\hline Denmark & $\infty$ & ळे & $\ddot{n}$ & $\nabla$ & 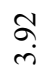 & I & ڤे & 2 & $\ddot{n}$ & $a$ & $\underset{\dot{+}}{\vec{\sigma}}$ & $m$ & $\stackrel{\infty}{\forall}$ & $N$ & $\underset{\forall}{\vec{f}}$ \\
\hline $\begin{array}{l}\text { United } \\
\text { Kingdom }\end{array}$ & $a$ & $\begin{array}{l}\text { ळे } \\
\text { }\end{array}$ & $\tilde{n}$ & 二 & $\stackrel{\hat{n}}{r}$ & $\infty$ & $\stackrel{\overbrace{}}{\dot{\gamma}}$ & 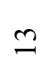 & $\begin{array}{l}\hat{\sigma} \\
\dot{r}\end{array}$ & $r$ & $\begin{array}{l}\stackrel{a}{o} \\
\dot{r}\end{array}$ & $\nabla$ & $\begin{array}{l}\exists \\
\dot{\sigma}\end{array}$ & in & $\stackrel{m}{\sigma}$ \\
\hline Finland & $\stackrel{0}{=}$ & $\hat{a}$ & à่ & $\infty$ & $\stackrel{N}{\infty}$ & $=$ & $\underset{+}{\stackrel{\circ}{+}}$ & 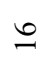 & $\stackrel{n}{n}$ & 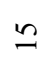 & $\stackrel{\infty}{\infty}$ & - & $\stackrel{N}{?}$ & $\infty$ & $\stackrel{\infty}{\sim}$ \\
\hline Russia & 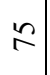 & $\frac{\circ}{i}$ & ì & a & 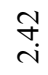 & $\overline{6}$ & $\stackrel{\infty}{\stackrel{\infty}{i}}$ & ๑ & $\begin{array}{l}\text { to } \\
i\end{array}$ & $\vec{\nabla}$ & $\frac{2}{i}$ & â & $\begin{array}{l}n \\
0 \\
i\end{array}$ & 8 & $\bar{m}$ \\
\hline
\end{tabular}

Russia's low position in the index could be explained as the result of lack of fully formulated IT-solution ecosystem. At the moment, there are numerous digital service providers offering solutions for logistical processes. The disparate state of IT-solutions makes the integration of different companies into a unified system impossible which, in turn, makes the interaction between the subjects so much more difficult. 


\section{Results}

The usage of overly specialized digital solutions can be considered a global issue. According to the Software Advice data [8], of 417 logistical digital solutions, not one of them can be considered universal or an ecosystem (Table 2). As such, companies have to rely on several different solutions to organize their logistical activity, which can be a cause of various inconveniences. Furthermore, process automation requires the integration of different digital technologies which is not always possible due to solutions being provided by different vendors.

Table 2. Digital solutions in logistics (Source: composed by the author based on [8]).

\begin{tabular}{|l|c|c|}
\hline \multirow{2}{*}{ Functional direction of IT solutions } & \multicolumn{2}{|c|}{ Number of IT solutions } \\
\cline { 2 - 3 } & Total. pcs & \% of the total \\
\hline $\begin{array}{l}\text { Warehouse Management Software } \\
\text { (WMS) }\end{array}$ & 169 & 40.5 \\
\hline $\begin{array}{l}\text { Transportation Management Systems } \\
\text { (TMS) }\end{array}$ & 142 & 34.1 \\
\hline Logistics Software & 143 & 34.3 \\
\hline Fleet Management Software & 210 & 50.6 \\
\hline $\begin{array}{l}\text { Contract Lifecycle Management } \\
\text { Software }\end{array}$ & 120 & 28.8 \\
\hline Dropshipping Software & 22 & 5.3 \\
\hline Demand Planning Software & 110 & 26.4 \\
\hline Order Fulfillment Software & 300 & 71.9 \\
\hline Order Entry Software & 212 & 50.8 \\
\hline Procurement Software & 171 & 41.0 \\
\hline Purchase Order Software & 243 & 58.3 \\
\hline Shipping Software & 128 & 30.7 \\
\hline Strategic Sourcing Software & 119 & 28.5 \\
\hline Supply Chain Planning Software & 164 & 39.3 \\
\hline SRM Software & 244 & 58.5 \\
\hline Vendor Management Systems & 196 & 47.0 \\
\hline VMI Systems & 148 & 35.5 \\
\hline & $\mathbf{4 1 7}$ & \\
\hline
\end{tabular}

The usage of specialized solutions can be convenient for small and mid-sized businesses due to their logistical activity being constrained to a small number of logistical operations. For the large businesses working with the full logistical cycle, it is necessary to possess a unified platform combining all the functional applications [9]. The usage of different digital solutions for various functional applications is expensive and inconvenient due to the requirement for integration of various solutions and automation of logistical processes.

That's why platform-based digital solutions became a major trend in the development of digital logistics [6]. Small and mid-sized businesses as well as large businesses that do not possess their logistical platform, could make the use of logistical platforms provided by an external vendor. This allows us to gain access to the full package of digital solutions required for the conduct of logistical operations [10].

Generally, we can speak of the evolution of digital solutions into platforms and platforms into ecosystems based on information exchange and existing ecosystems into their more complex versions. Based on this, authors have designated 3 key platform classes [11]:

-Intercompany platforms;

-Open-source general industry platforms;

- Platforms within value chains. 
A logistical ecosystem combines various digital solutions required to perform logistical operations, document flow, control, etc. Such an ecosystem must unify all participants of the digital logistics system according to their interests and role within logistical operations [12].

"Portal TransKonteiner" is a unified IT-system for container freight working under the one-stop-shop principle, works to unite participants from Russia, Belarus, Ukraine, the EU, and China. This system creates the framework of customs and border officials and expeditors, clients, representatives of "Portal TransKontainer", railway administration, and many others. The platform combines all the personnel participating in the logistical document flow in one place [13]. However, this platform mostly works with container freight.

Regarding the necessity to create a unified logistical platform which could unite all participants in logistical processes under one internet environment, we suggest a 3-level stakeholder interaction model, which aims to unite 10 categories of digital logistical ecosystem participants [14]:

-Regulatory bodies: Federal Customs Service, Federal Tax Service, etc.

-Terminals: commercial shipyards, airports, dry docks, etc.

- Logistical operators: expeditors, 3PL, etc.

- Transportation operators: railway, air, auto, and maritime.

- Logistical centers.

- Manufacturers.

- Providers/Consumers.

-Freight Senders/Receivers.

- Banks.

-Other participants.

On the current stage of the digital transformation, the interactions between the various participant categories are conducted through specialized digital solutions which complicate the activity of logistical companies [15]. The suggested 3-level model of stakeholder interaction could form the basis of the logistical platform's architecture (fig 2).

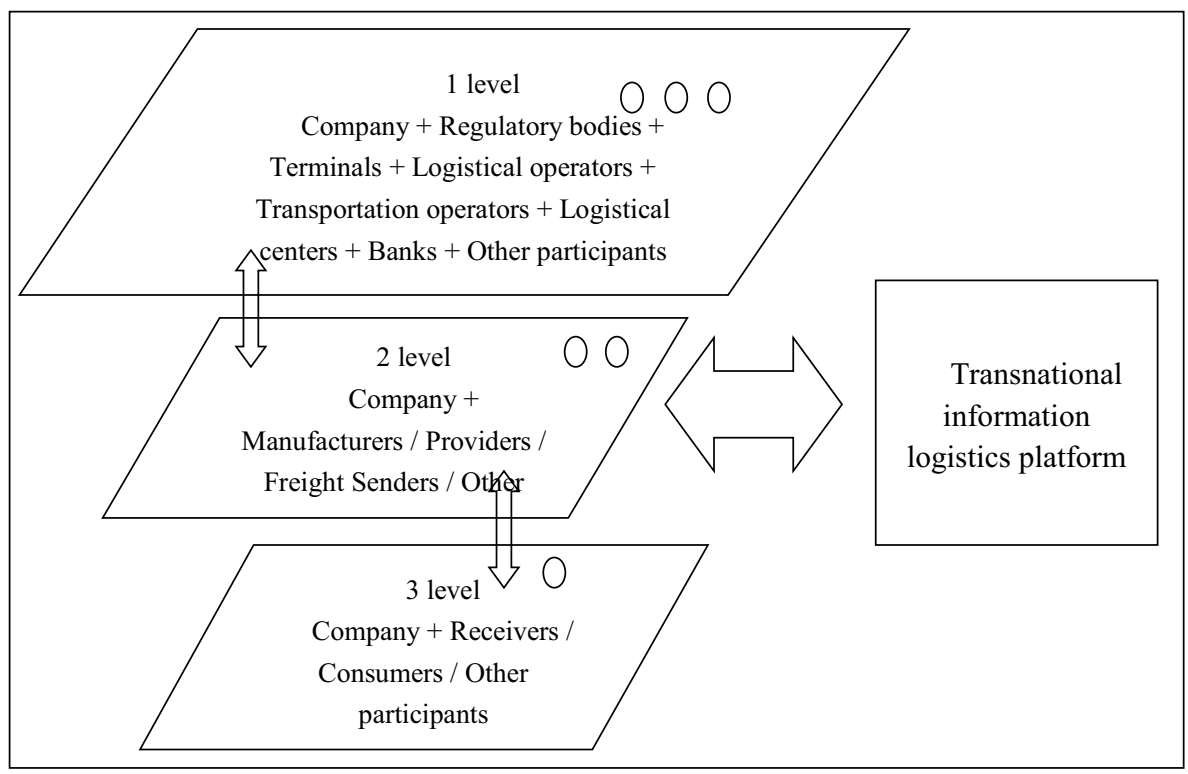

Fig. 3. 3-level logistical platform interaction model. 
Every level of the suggested model, in essence, unifies a company providing logistical services with various categories of stakeholders. This presentation is convenient in a way that each participant of the logistical platform has a personal cabinet providing a limited array of functions necessary for work based on the participant's role. Furthermore, every level of the platform has its informational security capability. The separation of the platform into distinct levels allows us to make it much more accessible to each user category and to structure the interactions between various stakeholders.

The first level combines all regulatory bodies, ports, terminals, logistical centers, transport, and logistical operators, banks, and other participants involved in logistical operations and related document flow. This level forms the basis of the platform because participant on this level has a measure of influence on all following levels.

The second level combines all of the participants who could be clients for a logistical company. Manufacturers, senders, and providers approach the company to delegate the execution of all necessary actions regarding cargo transportation. There is no need for interactions between this level participants, only an ability to communicate with logistical companies.

The third level is devoted to interactions between a logistical company and cargo receivers. Just like the second level, there's no need for this level participants to interact with each other.

Each level possesses its informational security capability, dictated by the varying levels of sensitive information contained within each level. The first level contains full information regarding the logistical process, while the second level only contains a limited amount of information adapted to the client. Consequently, the third levels contain the least amount of info necessary for cargo receivers/clients. To secure the information passed between the levels, all the data is hashed.

The interactions between the level's participants are dictated by the number of communications necessary to provide logistical services. The simplified model of such interactions is presented in fig 3 .

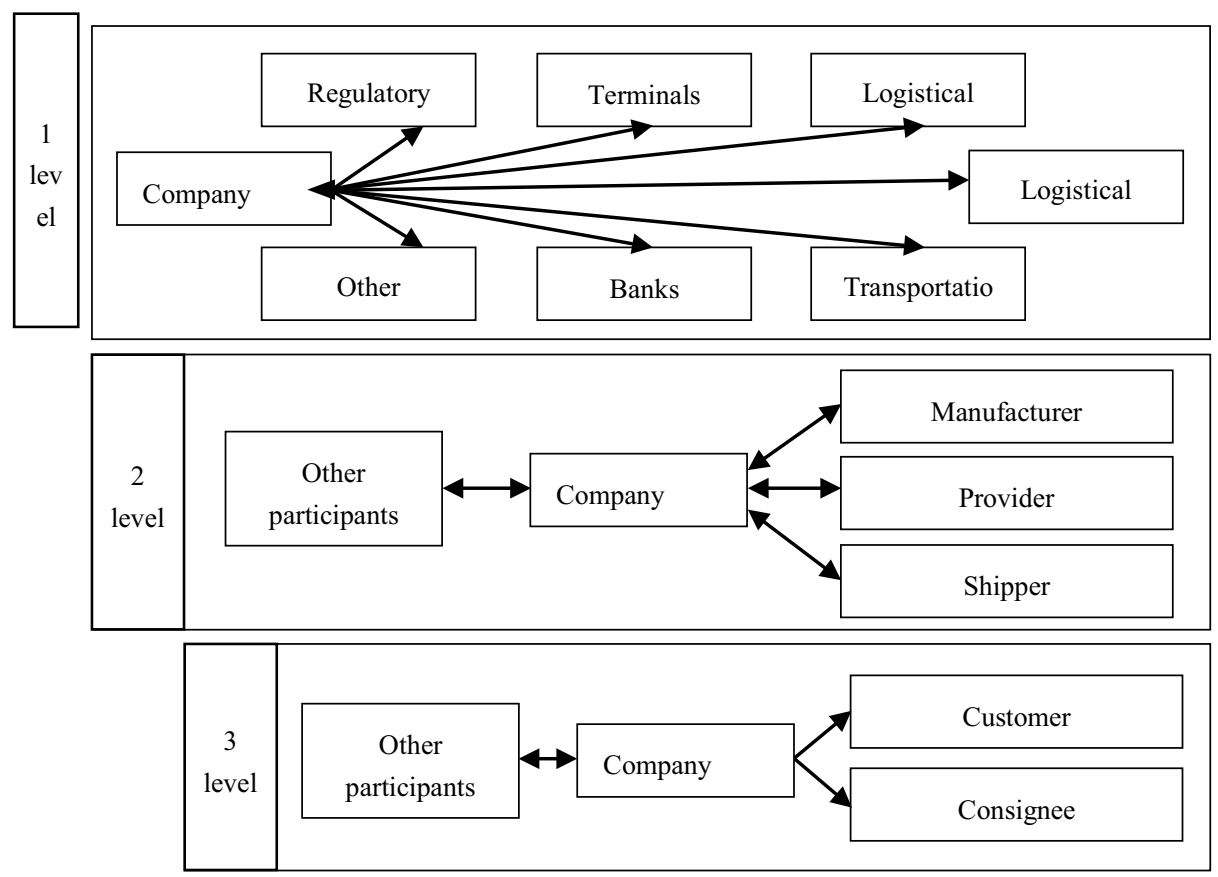

Fig. 4. The model of the principal interactions between stakeholders at all three levels. 
Following the information provided in fig 2, we could conclude that a company providing logistical services acts as a link between the 3 levels. It accumulates all the data and provides it to stakeholders of each level in the volume necessary.

\section{Discussion}

Digital platform development and application in business is a discussable issue among academics and practitioners, especially in the last two years. For instance, L. Richardson regards the approach to digital platforms as an Economic Space altering the geography of exchange and consumption, taking B2C examples such as Amazon, Airbnb, and Uber [16]. The authors of [17] pointed out the importance of the logistic methodology of development of the regional digital economy. The paper [18] developed a method for the ideation for digital platforms based on a companies' ecosystem in business-to-business context. The importance of the idea of integrated digital system applied to logistics was analyzed in [19] through the test Venkatraman's fit types. The discovery of the study is the high rank of popularity of the issue of supply chain integration in articles published in Scopus data base. Among subgroup of organization internal capabilities the eBusiness capabilities /technologies/applications was positioned at the second place with distinguishing such Antecedents as IT implementation, Integrative information technology, Cloud computing and Web 2.0, IT applications, Supply chain information system infrastructure. The authors conclude: “...papers focus on IT capabilities as a prerequisite of integration practices, where these capabilities are often strictly linked to integration forms, such as integrative information technology" [19]. The paper [20] makes focus on the one part of logistic process, distribution channels, analyzing digitally mediated shopping environments. The study [21] is investigating the application of Internet of Things within the service architecture of intelligent transport systems. The goal of the research presented in [22] is to explore the potential of different digital tools for mitigating barriers to the effective utilization of such specific type of logistic system as intermodal transport.

The object of the study of [15] is Internet of Things (IoT) in logistics enterprises. The interesting idea is proposed in the study of Nejc Rožman, Rok Vrabič, Marko Corn, Janez Diaci [23]. The article presents the concept of a new logistics platform that is built as a distributed network. It combines IoT and Blockchain which allows making the platform truly digital and bridging real and virtual world. The conceptual model of this study [23] consisting of three nodes organized into circle is similar to the model proposed by authors (fig. 2) consisting of three hierarchical level. The hierarchical structure on our opinion allows integrating logistics company with other stakeholders operating in their own accounts with a set of necessary options and security.

\section{Conclusions}

One of the major trends in digital logistics is the platform solutions, which provide a onestop place for all the participants of the logistical process. Currently, numerous specialized solutions can solve a limited set of goals.

Using various solutions for each of the steps of the process is inconvenient, due to the necessity of synchronization of data between different digital products, which is not always possible. Logistical platforms should solve this issue due to providing all the necessary functions and combining all of the participants.

Authors suggested the 3 level model for stakeholder interaction on a logistical platform, which could form the basis of the platform solution's architecture. The provided model reflects all of the interactions which can occur between the participants and the necessary 
levels of security for each of the levels. However, the issue of the functional contents of such a platform remains open and will be a subject of future studies.

\section{References}

1. A.A. Koroleva, Journal of the Belarusian State University. Economy (2019) https://www.elibrary.ru/item.asp?id=38535233

2. I.V. Terenina, E.V. Skovorodneva, Bulletin of the Rostov State University of Economics (RINH) (2018) https://www.elibrary.ru/item.asp?id=36588838

3. I.V. Bordunov, Economy: yesterday, today, tomorrow https://www.elibrary.ru/item.asp?id=43983578

4. National program "Digital Economy of the Russian Federation", http://government.ru/rugovclassifier/614/events/

5. Digital technologies in logistics (First National Consulting Group) http://www.fncgroup.ru/en/cifrovie-technologii-v-logistike.html

6. E. Anisina, New urban economy https://spb.plus.rbc.ru/news/5d7f84c47a8aa95f6d08db44

7. A.V. Dmitriev, Strategic solutions and risk management (2019) https://cyberleninka.ru/article/n/tsifrovye-tehnologii-proslezhivaemosti-gruzov-vtransportno-logisticheskih-sistemah.

8. Software Advice official site, https://www.softwareadvice.com/scm/

9. A. Shichkov, V. Gluhov, IOP Conference Series: Materials Science and Engineering (2019) https://doi.org/10.1088/1757-899X/497/1/012093

10. V. Orlova, I. Ilin, S. Shirokova, MATEC Web of Conferences 193 (2018)

11. V.L. Vasilenok, A.I. Kruglova, E.I. Aleksashkina et al., Scientific journal of NRU ITMO. Series Economics and Environmental Management (2020) http://economics.ihbt.ifmo.ru/file/article/19478.pdf

12. S. Maydanova, I. Ilin, A. Lepekhin, Proceedings of the 33rd International Business Information Management Association Conference, IBIMA 2019: Education Excellence and Innovation Management through Vision 2020, 5103-5111 (2019)

13. G.V. Bubnova, B.A. Levin, International Journal of Open Information Technologies (2017) https://cyberleninka.ru/article/n/tsifrovaya-logistika-innovatsionnyy-mehanizmrazvitiya-i-effektivnogo-funktsionirovaniya-transportno-logisticheskih-sistem-i

14. I.A. Mikhailovsky, The concept of building a national platform for the system of electronic logistics (Research Institute of Applied Software Systems, 2019) https://digitalrzd.ru/f/prezentaciya_ipps.pdf

15. I.V. Ilin, D.D. Bolobonov, A.K. Frolov, Proceedings of the 33rd International Business Information Management Association Conference, IBIMA 2019: Education Excellence and Innovation Management through Vision 2020, 5092-5102 (2019)

16. L. Richardson, Digital and Platform Economies. International Encyclopedia of Human Geography (Second Edition) (2020)

17. V. Vilken, O. Kalinina, S. Barykin, E. Zotova, IOP Conference Series: Materials Science and Engineering (2019) https://doi.org/10.1088/1757-899X/497/1/012037

18. F. Wortmann, K. Ellermann, A. Kühn, R. Dumitrescu, Procedia CIRP 91, 559-564 (2020) 
19. P. Danese, M. Molinaro, P. Romano, Journal of Purchasing and Supply Management 100634 (2020)

20. B. Burroughs, W.J. Burroughs, Technology in Society 62, 101277 (2020)

21. A.I. Levina, A.S. Dubgorn, O.Y. Iliashenko, Proceedings - 2017 European Conference on Electrical Engineering and Computer Science, EECS 2017, 351-355 (2018)

22. Ceren Altuntaş, Vural Violeta Roso, Árni Halldórsson, M. Yaruta, Can digitalization mitigate barriers to intermodal transport? An exploratory study. Research in Transportation Business \& Management (2020)

23. N. Rožman, R. Vrabič, M. Corn, J. Diaci, Procedia CIRP 81, 826-831 (2019) 